\title{
Does milk treatment before cheesemaking affect microbial and chemical traits of ripened cheese? Grana Trentino as a case study
}

\author{
E. Franciosi, ${ }^{1}$ F. Gardini,† L. Monfredini, ${ }^{\star}$ G. Tabanelli,† A. Fabris, ${ }^{\star}$ I. Endrizzi, ${ }^{\star}$ E. Poznanski, ${ }^{\star}$ F. Gasperi, ${ }^{*}$ \\ and A. Cavazza* \\ ${ }^{*}$ IASMA Research and Innovation Centre-Fondazione Edmund Mach, Food Quality and Nutrition Department, Via E. Mach 1, \\ 38010 S. Michele a/Adige (TN), Trentino, Italy \\ †Department of Food Science, University of Bologna, Piazza Goidanich 60, 47023 Cesena (FC), Italy
}

\section{ABSTRACT}

The aim of this study was to evaluate the influence of different storage temperatures and delivery system of the milk on the microbiological and physicochemical characteristics of Grana Trentino, a long-ripened hardcooked Italian cheese. In particular, 3 kinds of milk storage and delivery were studied: milk delivered to the dairy in the traditional manner without temperature control, milk delivered at $18^{\circ} \mathrm{C}$, and milk stored at the farm and delivered at $12^{\circ} \mathrm{C}$. Milk, natural whey starter, and cheeses after 18 mo of ripening were sampled for microbiological profiles, physicochemical analysis, and proteolysis evaluation, and a study of cheese volatile compounds through a solid-phase microextraction gas chromatography-mass spectrometry technique was performed. Milk microbiota was not affected by any of the treatments. At the end of ripening, free fatty acid and ester contents were significantly higher in cheeses from milk without temperature control. This was probably due to the milk delivery to the dairy in churns causing the fat globule membrane break during transport and, consequently, a greater release of fat and deeper lipolysis. Milk refrigeration at $12^{\circ} \mathrm{C}$ for $12 \mathrm{~h}$ before delivery affected the distribution of nitrogen fractions in cheeses. Lower temperatures of milk storage favored a larger soluble nitrogen fraction and greater cheese proteolysis, probably caused by an enhanced plasmin activity. From this work, it is concluded that both milk temperature storage and transport system could affect cheese ripening, leading to significant differences in chemical compounds: if milk was delivered by churns, higher free fatty acid and ester content in cheeses was observed; if milk was stored at $12^{\circ} \mathrm{C}$ for $12 \mathrm{~h}$ before delivery, greater cheese proteolysis was induced with consequent faster ripening.

Received July 6, 2011.

Accepted April 28, 2012.

${ }^{1}$ Corresponding author: elena.franciosi@iasma.it
Key words: hard cheese, milk treatment, microbiota, volatile organic compound

\section{INTRODUCTION}

Grana Trentino is an Italian Protected Designation of Origin (PDO) hard-cooked cheese, similar to Parmigiano Reggiano and Grana cheeses, and is produced in the Trentino region (Alpine area located in the northern part of Italy) from partially skimmed raw cow milk. Grana Trentino belongs to the Grana Padano Consortium, but has a clear manufacturing technology distinct from other Grana-like cheeses [European Community (EC) regulation no. 1107/96]. In Grana Padano production, raw milk comes mainly from Italian Friesian herds breed in the Padana Valley; more than one cheesemaking per day is allowed in the cheese factory and lysozyme is used. In Grana Trentino production, only one cheesemaking per day is allowed in the cheese factory and, moreover, the use of lysozyme is forbidden. Milk comes mainly from Brown Swiss herds, which are a breed in the valleys of the Alps without ensilage feeding. Cheeses manufactured by milk from Brown Swiss cows usually have a higher casein content, better rheological properties, and lower losses of fat than those produced by Italian Friesian cow milk (Malacarne et al., 2006; De Marchi et al., 2008). Usually, the milk is not subjected to any temperature control or it is mildly cooled to $18^{\circ} \mathrm{C}$ before delivery.

Traditionally, milk is not refrigerated or subjected only to mild refrigeration; the morning and evening milkings are delivered in the shortest time to avoid microbial proliferation before cheesemaking. Milk transport to the dairy factory occurs twice per day in $50-\mathrm{L}$ milk churns or by road tanker if refrigerated at $18^{\circ} \mathrm{C}$. To reduce costs and labor, a different cheesemaking system based on a single collection of refrigerated milk is under evaluation. Milk refrigeration could allow rationalization of the collection routes, reduction of transport costs, and increased flexibility both on farm and during milk processing. Moreover, the microbiological risks 
arising from the use of churns and milk contact with the air will be reduced together with possible microbial spoilage proliferation during overnight milk creaming (Franciosi et al., 2011).

However, under refrigeration, milk may undergo changes in its physical, chemical, biochemical, and microbiological composition and also have negative effects on the characteristics of produced cheeses (Franceschi et al., 2008). Milk refrigeration could lead to higher plasmin activation (Fajardo-Lira et al., 2000) and to proliferation of psychrotrophic bacteria, which are known to produce active and thermostable proteolytic and lipolytic enzymes that can affect cheese quality (Cousin, 1982; Wiedmann et al., 2000). Whether due to psychrotrophic bacteria activity, milk proteolysis causes losses of soluble nitrogen in the whey, and consequently reduces the cheese protein content (Snoeren and van Riel, 1979). The thermostable lipolytic enzymes of psychrotrophic bacteria may survive the cooking process that occurs during cheesemaking, and could increase the cheese FFA concentrations during ripening, negatively affecting cheese organoleptic properties (Wiedmann et al., 2000). Moreover, during refrigeration, a partial solubilization of the casein components occurs, and $\beta-\mathrm{CN}$ separates from the micelles, causing a reduction of the protein fraction in cheese. Finally, an increase in the content of soluble inorganic calcium and phosphorus is common in refrigerated milk, increasing the resistance of casein micelles to rennet and leading to lower casein content in cheese (Alais, 2000). These changes wrought by milk refrigeration have the potential to significantly affect important quality parameters in the final cheese, especially the degree of proteolysis, fat content, and fat derivates. Cheese proteolysis is a very important index of ripening in hard cheeses such as Grana Trentino and is related to the ripening time. Hard cheeses that have a low free AA content are not desirable and require longer ripening (Mucchetti and Neviani, 2006b).

Few studies have focused on the impact of milk refrigeration on cheese quality. Tavaria et al. (2006) looked for microbial and microstructure variations in Serra de Estrela cheese produced from refrigerated milk and they observed a less compact coagulum in cheeses manufactured with refrigeration.

The aim of the present work was to evaluate whether different collection and storage procedures of milk before cheesemaking could affect the microbial and chemical characteristics of Grana Trentino cheese. The ripening degree after 18 mo was checked in cheeses produced with milk delivered once per day or twice per day to the cheese factory. In the once-per-day milk delivery, the morning milk was kept on farm and refrigerated at $12^{\circ} \mathrm{C}$ for $12 \mathrm{~h}$, and then delivered together with that coming from the evening milking. This procedure was compared with the twice-per-day delivery of the milk where each of the 2 milkings (morning and evening) were separately delivered to the cheese factory in a temperature-controlled truck if the milk was cooled at $18^{\circ} \mathrm{C}$, or in $50-\mathrm{L}$ churns if without any temperature control. In previous work, we (Endrizzi et al., 2012) investigated the perception of sensory differences by triangle test among 24 Grana Trentino cheeses produced in 1 cheese factory, with milk delivered once per day and refrigerated at 12 or $8^{\circ} \mathrm{C}$, and milk delivered twice per day at 2 different temperatures. Differences were detected by a trained panel, but not by a consumer panel, only when comparing traditional milk collection twice per day by churns with the milk refrigerated at the lowest temperature $\left(8^{\circ} \mathrm{C}\right)$, indicating that the sensory effects of milk refrigeration on Grana Trentino may be negligible if it is at $12^{\circ} \mathrm{C}$. In the present study, we compared all of the previous methods of milk storage and delivery (with the exception of the 6 samples after $8^{\circ} \mathrm{C}$ treatment), to discover if any microbial and chemical differences could be found among cheeses produced after milk treatments when sensory differences were not perceivable. The number of samples was enlarged by including 2 more cheese factories in the experimental plan. Milk, natural whey starter, and 18-mo-ripened cheeses were sampled for microbial viable counts, nitrogen fractions, free AA (FAA), and volatile organic compounds (VOC).

\section{MATERIALS AND METHODS}

\section{Milk Treatments}

Samples were collected in 3 Grana Trentino-producing dairy factories belonging to the Trentingrana Consortium during 38 cheesemaking days from April 2007 to May 2008. Milk was stored at the farm in 3 different conditions before its delivery: (1) without refrigeration, (2) cooled at $18 \pm 1^{\circ} \mathrm{C}$, or (3) cooled at $12 \pm 1^{\circ} \mathrm{C}$. When milk was stored without refrigeration, morning and evening milkings were delivered separately, twice in a day, in 50-L milk churns [treatment without temperature control (WTC); 9 replicates]. Even when milk was cooled at $18^{\circ} \mathrm{C}$, morning and evening milkings were delivered separately in a temperature-controlled road tanker (10 replicates). For milk cooled to $12^{\circ} \mathrm{C}$, the morning milking was kept in a refrigerated tank at the farm under mild stirring for $12 \mathrm{~h}$ and then mixed with the evening milking and delivered once per day to the dairy factory in a temperature-controlled road tanker (19 replicates). All of the analyses were carried out on samples collected from days with a high degree of homogeneity in terms of the vat milk fat and protein content (these parameters are strongly influenced by 
the cheesemaker, creaming, and technological conditions), and natural whey starter (NWS) $\mathrm{pH}$ and microbial counts, as NWS bacterial microbiota is involved in cheese ripening and of primary importance in cheese quality (Coppola et al., 1997, 2000).

\section{Cheesemaking}

Raw milk delivered in the evening was spontaneously skimmed overnight in shallow tanks. Skim milk was then put in a copper vat and heated to $22 \pm 2^{\circ} \mathrm{C}$. For the WTC and $18^{\circ} \mathrm{C}$ treatments, the morning milking was added to the skimmed evening milking in the vat before cheesemaking. Natural whey starter (about 30 L) was added to the vat containing about $1,030 \mathrm{~kg}$ of milk, bringing the $\mathrm{pH}$ of the mix to $6.4 \pm 0.1$. Milk was heated to $33 \pm 1{ }^{\circ} \mathrm{C}$ and coagulation occurred after the addition of calf rennet powder. The curd was broken up for 2 to $3 \mathrm{~min}$ and the temperature was raised gradually to between 42 and $44^{\circ} \mathrm{C}$. The temperature was then raised quickly to $55 \pm 1.0^{\circ} \mathrm{C}$ in 8 to $10 \mathrm{~min}$ to cook the curd. After a 60-min rest, the curd was removed and cut to obtain 2 twin wheels. After molding, the 2 wheels were held for $2 \mathrm{~d}$ at $20^{\circ} \mathrm{C}$ and frequently turned to drive off all of the whey. They were then salted by immersion in brine (280 to $300 \mathrm{~g}$ of $\mathrm{NaCl} / \mathrm{L}$ at 15 to $18^{\circ} \mathrm{C}$ for 20 to $25 \mathrm{~d}$ ). The cheese wheels were 20 to 25 $\mathrm{cm}$ in height, with a $30-$ to $35-\mathrm{cm}$ diameter and their weight was 35 to $40 \mathrm{~kg}$. Ripening was done at $80 \%$ relative humidity, at about $18^{\circ} \mathrm{C}$ for 18 mo.

\section{Sampling Procedures}

Aliquots of vat milk were sampled both for chemical and microbiological samples. After 18 mo ripening, for each of the 38 cheesemaking days, 1 of the 2 twin wheels was cut along the vertical axis to obtain 2 symmetrical half wheels. For microbiological analysis, one 20-g dish-shaped sample was collected from along the diagonal: $10 \mathrm{~cm}$ far from over-dish edge and $15 \mathrm{~cm}$ far from the rind of the lateral side.

For physicochemical analysis, a quarter of cheese was cut in 3 blocks: 1 for basic chemical analysis (composition and proteolysis evaluation), 1 for FAA quantification, and 1 for VOC analysis. They were all stored under vacuum at $-20^{\circ} \mathrm{C}$. Before analysis, the cheese samples were thawed at $4^{\circ} \mathrm{C}$ overnight and from each piece the rind and the external layer (minimum $1 \mathrm{~cm}$ ) were removed and a slice of about $12 \times 6 \times 1.5 \mathrm{~cm}$ was cut and grated.

\section{Media and Plate Count Conditions}

Ten-gram cheese samples from each of the 38 test days were taken aseptically, placed in sterile $(500-\mathrm{mL}$ capac- ity) stomacher bags, diluted with $90 \mathrm{~mL}$ of $2 \%$ sodium citrate solution ( $\mathrm{pH} 5.5$ ), and homogenized in a blender (Stomacher 400, Seward Medical, London, UK). Each vat milk and cheese sample was serially diluted in peptone water $(0.1 \%$ mycological peptone; Oxoid, Milano, Italy). All of the samples were plated in triplicate. Total mesophilic and psychrotrophic bacteria were counted on plate count agar (Oxoid) added to $1 \mathrm{~g} / \mathrm{L}$ of skim milk (Oxoid), incubated aerobically at $30^{\circ} \mathrm{C}$ for $24 \mathrm{~h}$ and at $7^{\circ} \mathrm{C}$ for $7 \mathrm{~d}$ for mesophilic and psychrotrophic bacteria, respectively. Thermophilic lactic acid bacteria were counted anaerobically on whey agar medium, prepared as reported by Gatti et al. (2003), after anaerobic incubation for $3 \mathrm{~d}$ at $45^{\circ} \mathrm{C}$. Mesophilic lactic acid bacteria rods and cocci were counted on de Man, Rogosa, and Sharpe (MRS) and M17 agar, incubated at $30^{\circ} \mathrm{C}$ anaerobically for $48 \mathrm{~h}$ and aerobically for $24 \mathrm{~h}$, respectively. Clostridial numbers were estimated by the most probable number technique using a $3 \times 3$ scheme: undiluted samples and decimal dilutions were pasteurized at $85^{\circ} \mathrm{C}$ for 15 min and inoculated into reinforced clostridial medium (Oxoid) supplemented with $1.4 \%$ (vol/vol) Na-lactate (Merck KGaA, Darmstadt, Germany); after that, test tubes were sealed with paraffin:petroleum jelly (1:6) and incubated for $7 \mathrm{~d}$ at $37^{\circ} \mathrm{C}$.

\section{Physicochemical Analysis}

Milk temperatures were registered from the arrival to the cheese factory to the end of the cheesemaking process using a 175-T2 data logger (Testo AG, Settimo Milanese, Milano, Italy). The $\mathrm{pH}$ values of vat milk were measured by means of a portable $\mathrm{pH}$ meter (Knick Portamess 910; Knick Elektronische Messgeräte GmbH \& Co. KG, Berlin, Germany) connected to a Cheesetrode (Hamilton Co., Reno, NV) electrode. Fat and protein contents in milk were evaluated by infrared analysis (Biggs, 1978) with a MilkoScan 134 A/B (Foss Electric A/S, Hillerød, Denmark). In cheeses, the DM contents were determined using an oven at $102^{\circ} \mathrm{C}$ (FILIDF 4/A:1982; IDF, 1982), the fat contents following the Gerber-Siegfeld method (Savini, 1946), and $\mathrm{NaCl}$ contents by titrating with $\mathrm{AgNO}_{3}$ (FIL-IDF 88/A:1988; IDF, 1988). The water activity under the rind and in the core was measured using an AquaLab model Series 3 water activity meter (Decagon Devices Inc., Pullman, Washington).

\section{Proteolysis}

Cheese protein quantity was determined by the Kjeldahl method according to Bütikofer et al. (1993). The total nitrogen $(\mathbf{T N})$ and soluble nitrogen $(\mathbf{S N})$ values at $\mathrm{pH} 4.6$ were obtained as described by Gripon et al. 
(1975). The ripening index (RI) was calculated from the ratio of water-soluble nitrogen to TN.

Quantification of FAA in cheeses was achieved after $\mathrm{HClO}_{4}$ treatment, using an Agilent $1100 \mathrm{HPLC}$ (Agilent Technologies GmbH, Waldbronn, Germany) system and the Agilent ChemStation software. A Merck LiChrospher 100 RP-18 spherical silica gel carrier (250 $\times 4.6 \mathrm{~mm}$; $5 \mathrm{~mm}$; Merck KGaA) was used. All of the instrumental analytic conditions were as described by Larcher et al. (2004). Samples from each of the 38 test days were prepared in triplicate and the results were expressed as means \pm standard deviations.

\section{Analysis of VOC}

Samples were analyzed according to a solid-phase microextraction GC-MS technique based on the procedure described by Carlin and Versini (2005) and subsequently optimized as follows: about $3 \mathrm{~g}$ of the grated cheese was placed in a glass vial $(20 \mathrm{~mL}$; Supelco Inc., Bellefonte, PA) with $4 \mathrm{~mL}$ of bidistilled water, $50 \mu \mathrm{L}$ of a solution of 3 internal standards (0.0509 g of 4-methyl2-pentanone/L, Sigma-Aldrich, Milan, Italy; $0.06 \mathrm{~g}$ of ethyl heptanoate/L, Sigma-Aldrich; and $20.021 \mathrm{~g}$ of isobutyric acid/L, Fluka, Milan, Italy; purity $\geq 99 \%$ ) with a magnetic stir bar and capped by polytetrafluoroethylene (PTFE)/silicone septa (Supelco Inc.).

The cheese sample was equilibrated at $40^{\circ} \mathrm{C}$ for 30 min under stirring $(750 \mathrm{rpm})$ and then a fused silica fiber coated with divinylbenzene/Carboxen/polydimethylsiloxane (DBV/CAR/PDMS) 50/30 $\mu \mathrm{m}$ (Supelco Inc.) was introduced and exposed to the headspace environment for $30 \mathrm{~min}$. Volatiles adsorbed on SPME fiber were desorbed at $250^{\circ} \mathrm{C}$ in the injector of a $\mathrm{GC}$ interfaced with a mass detector, which operate in electron ionization mode (EI, internal ionization source; 70 $\mathrm{eV}$ ) with a scan range from $m / z 30$ to 300 (GC Clarus 500; PerkinElmer Inc., Norwalk, CT). Procedure phases were automatically managed using a self-sampling system (CTC combi PAL; CTC Analysis AG, Zwingen, $\mathrm{CH})$. Separation was achieved on an HP-Innowax fusedsilica capillary column $(30 \mathrm{~m}, 0.32 \mathrm{~mm}$ i.d., $0.5-\mu \mathrm{m}$ film thickness; Agilent Technologies, Palo Alto, CA). The $\mathrm{GC}$ oven temperature program consisted of $40^{\circ} \mathrm{C}$ for 3 min, 40 to $180^{\circ} \mathrm{C}$ at $4^{\circ} \mathrm{C} / \mathrm{min}, 180^{\circ} \mathrm{C}$ for $6 \mathrm{~min}$, and then 180 to $220^{\circ} \mathrm{C}$ at $5^{\circ} \mathrm{C} / \mathrm{min}$. Helium was used as the carrier gas with a constant column flow rate of $2 \mathrm{~mL} / \mathrm{min}$. Compound identifications were based on mass spectra matching in the standard NIST05 (NIST/EPA/NIH, 2005) library and retention times of authentic reference standards. Samples from each of the 38 test days were prepared in triplicate and the results were expressed as means \pm standard deviations.

\section{Statistical Analysis}

All of the data were subjected to one-way ANOVA, followed by the Tukey post-hoc test for unequal $n$ (Spjøtvoll-Stoline test) using the Statistica data analysis software system, version 9.1 (StatSoft Inc., Tulsa, OK; http://www.statsoft.com). Differences were considered significant at $P<0.05$. To help interpret the results of all analysis performed on cheese samples, a reduced number of variables related to cheese analyses were evaluated by principal component (PC) analysis on the correlation matrix using the same statistical package as for ANOVA.

\section{RESULTS AND DISCUSSION}

\section{Microbiological and Physicochemical Characteristics of Milk and NWS Before Cheesemaking}

Mean milk temperatures recorded upon delivery at the dairy factory were $30.2^{\circ} \mathrm{C} \pm 2.0$ for the WTC treatment, $18.2^{\circ} \mathrm{C} \pm 0.9$ for the $18^{\circ} \mathrm{C}$ treatment, and $12.0^{\circ} \mathrm{C} \pm 1.8$ for the $12^{\circ} \mathrm{C}$ treatment. Table 1 reports the composition (fat and protein content), $\mathrm{pH}$, and microbial counts of the vat milk under the 3 different milk storage/delivery systems. According to the ANOVA results, the milk treatment did not significantly influence physicochemical properties nor the microbiological viable counts in milk before cheesemaking. Mesophilic cocci count mean values ranged from 3.6 to $4.1 \mathrm{log}$ $\mathrm{cfu} / \mathrm{mL}$ and were the dominant bacterial group present in all milk samples. The predominance of cocci in raw milk collected in the same region was previously reported (Franciosi et al., 2011). Psychrotroph count mean values ranged from $2.9\left(12^{\circ} \mathrm{C}\right.$ milk treatment $)$ to $3.5 \log \mathrm{cfu} / \mathrm{mL}$ (WTC milk treatment), showing that the milk refrigeration at $12^{\circ} \mathrm{C}$ and its storage at the farm for $12 \mathrm{~h}$ did not enhance any spoilage bacteria growth. In accordance with a previous study (Franciosi et al., 2011), no aerobic spore-forming bacteria was found. The NWS thermophilic counts were not significantly different between milk treatments; their mean values ranged between 7.4 and $7.7 \log \mathrm{cfu} / \mathrm{mL}$ and their $\mathrm{pH}$ between 3.2 and 3.4 (data not shown).

\section{Microbiological and Physicochemical Characteristics of Cheese}

Table 2 reports the microbial counts in the cheeses made with milk that had undergone the 3 different storage/delivery conditions. Mesophilic rods were the dominant group, ranging between 3.9 and $5.2 \mathrm{log} \mathrm{cfu} /$ $\mathrm{mL}$. Similar counts were obtained on plate count agar 
Table 1. Mean counts (log cfu/mL) of the main microbial groups, $\mathrm{pH}$, and protein and milk fat content $(\mathrm{g} / 100$ g) in Grana Trentino vat milk from different milk treatments: milk stored without temperature control and delivered by churns (WTC), milk stored at $18^{\circ} \mathrm{C}\left(18^{\circ} \mathrm{C}\right)$, and milk stored at $12^{\circ} \mathrm{C}\left(12^{\circ} \mathrm{C}\right)$ for $12 \mathrm{~h}^{1}$

\begin{tabular}{lcccc}
\hline & \multicolumn{3}{c}{ Treatment } \\
\cline { 2 - 4 } Item & WTC & $18^{\circ} \mathrm{C}$ & $12^{\circ} \mathrm{C}$ & Significance \\
\hline Total bacteria & $4.3 \pm 0.7$ & $4.2 \pm 0.7$ & $3.8 \pm 0.8$ & $\mathrm{NS}^{2}$ \\
Mesophilic cocci & $4.1 \pm 0.5$ & $4.1 \pm 0.6$ & $3.8 \pm 0.8$ & $\mathrm{NS}$ \\
Mesophilic rods & $3.2 \pm 0.5$ & $3.0 \pm 0.6$ & $2.8 \pm 1.1$ & $\mathrm{NS}$ \\
Thermophilic lactic acid bacteria & $2.4 \pm 1.2$ & $2.6 \pm 0.8$ & $1.8 \pm 1.1$ & $\mathrm{NS}$ \\
Psychrotrophs & $3.5 \pm 0.7$ & $3.0 \pm 0.9$ & $2.9 \pm 1.3$ & $\mathrm{NS}$ \\
pH & $6.39 \pm 0.08$ & $6.40 \pm 0.05$ & $6.42 \pm 0.04$ & $\mathrm{NS}$ \\
Protein & $3.49 \pm 0.07$ & $3.52 \pm 0.11$ & $3.51 \pm 0.09$ & $\mathrm{NS}$ \\
Fat & $2.47 \pm 0.16$ & $2.57 \pm 0.19$ & $2.50 \pm 0.17$ & $\mathrm{NS}$ \\
\hline
\end{tabular}

${ }^{1}$ Results are shown as mean values \pm SD.

${ }^{2} P>0.05$.

used for total microflora enumeration. The lactobacilli prevalence has also been observed in other Grana-like cheeses (Coppola et al., 1997, 2000). Mean values of the total bacterial and mesophilic rod counts were significantly lower in cheeses produced with milk refrigerated at $12^{\circ} \mathrm{C}$ than when milk was cooled at $18^{\circ} \mathrm{C}$.

Physicochemical characteristics, TN and SN, and the RI values of Grana Trentino cheeses are reported in Table 2. Differences in $\mathrm{pH}$, water content, proteins, lipid concentration, and $\mathrm{NaCl}$ content of the cheeses were not significant.
The amount of SN was significantly higher in cheeses from milk cooled at 12 than at $18^{\circ} \mathrm{C}$. The TN and SN fraction mean values ranged between 5.09 and 5.24 and between 1.30 and $1.45 \mathrm{~g} / 100 \mathrm{~g}$, respectively. Lower protein content due to mineral changes and partial casein solubilization of refrigerated milk (Alais, 2000) in cheese from milk cooled at $12^{\circ} \mathrm{C}$ was supposed, but no variability was recorded in cheese protein and $\mathrm{TN}$ fractions (Table 2). The SN fraction contains the majority of AA and low-molecular weight peptides that are more involved in cheese taste than large and medium-sized

Table 2. Mean counts (log cfu/g) of the main microbial groups and basic composition (g/100 g) of Grana Trentino cheese at 18 mo of ripening from milk with different treatments before cheesemaking: milk stored without temperature control and delivered by churns (WTC), milk stored at $18^{\circ} \mathrm{C}\left(18^{\circ} \mathrm{C}\right)$, and milk stored at $12^{\circ} \mathrm{C}\left(12^{\circ} \mathrm{C}\right)$ for $12 \mathrm{~h}^{1}$

\begin{tabular}{|c|c|c|c|c|}
\hline \multirow[b]{2}{*}{ Item } & \multicolumn{3}{|c|}{ Treatment } & \multirow[b]{2}{*}{ Significance } \\
\hline & WTC & $18^{\circ} \mathrm{C}$ & $12^{\circ} \mathrm{C}$ & \\
\hline Total bacteria & $4.6 \pm 0.9^{\mathrm{ab}}$ & $5.2 \pm 0.8^{\mathrm{b}}$ & $4.4 \pm 1.0^{\mathrm{a}}$ & $*$ \\
\hline Mesophilic cocci & $3.0 \pm 1.8$ & $3.6 \pm 2.1$ & $2.8 \pm 1.8$ & $\mathrm{NS}^{2}$ \\
\hline Mesophilic rods & $4.6 \pm 1.0^{\mathrm{ab}}$ & $5.1 \pm 0.7^{\mathrm{b}}$ & $3.9 \pm 1.6^{\mathrm{a}}$ & * \\
\hline Thermophilic lactic acid bacteria & $1.2 \pm 0.6$ & $1.2 \pm 1.6$ & $1.6 \pm 1.5$ & NS \\
\hline Psychrotrophs & $\mathrm{ND}^{3}$ & ND & ND & NS \\
\hline $\mathrm{pH}$ & $5.43 \pm 0.05$ & $5.43 \pm 0.03$ & $5.44 \pm 0.06$ & NS \\
\hline Moisture & $32.31 \pm 0.37$ & $32.26 \pm 0.80$ & $32.03 \pm 0.95$ & NS \\
\hline $\mathrm{DM}$ & $67.69 \pm 0.37$ & $67.74 \pm 0.80$ & $67.97 \pm 0.95$ & NS \\
\hline Fat & $27.0 \pm 1.0$ & $27.7 \pm 1.5$ & $27.4 \pm 2.0$ & NS \\
\hline Protein & $32.9 \pm 1.2$ & $32.5 \pm 1.5$ & $33.41 \pm 0.88$ & NS \\
\hline $\mathrm{NaCl}$ & $1.78 \pm 0.10$ & $1.73 \pm 0.15$ & $1.69 \pm 0.15$ & NS \\
\hline $\mathrm{NaCl} /$ moisture (\%) & $5.50 \pm 0.33$ & $5.35 \pm 0.49$ & $5.29 \pm 0.55$ & NS \\
\hline $\mathrm{TN}^{4}$ & $5.13 \pm 0.19$ & $5.09 \pm 0.23$ & $5.24 \pm 0.14$ & NS \\
\hline $\mathrm{SN}^{5}$ & $1.33 \pm 0.08^{\mathrm{ab}}$ & $1.30 \pm 0.13^{\mathrm{a}}$ & $1.45 \pm 0.13^{\mathrm{b}}$ & $* * *$ \\
\hline $\mathrm{SN} \% / \mathrm{TN}(\mathrm{RI})^{6}$ & $25.9 \pm 1.4^{\mathrm{ab}}$ & $25.4 \pm 1.8^{\mathrm{a}}$ & $27.6 \pm 2.1^{\mathrm{b}}$ & $* * *$ \\
\hline
\end{tabular}

$\overline{\mathrm{a}, \mathrm{b}}$ Values within a row with different superscript letters are significantly different $(P<0.05)$.

${ }^{1}$ Results are shown as mean values $\pm \mathrm{SD}$.

${ }^{2} P>0.05$.

${ }^{3}$ Not detected $(<50 \mathrm{cfu} / \mathrm{g})$.

${ }^{4} \mathrm{TN}=$ total $\mathrm{N}$.

${ }^{5} \mathrm{SN}=\mathrm{pH} 4.6$-soluble nitrogen.

${ }^{6} \mathrm{SN} \% / \mathrm{TN}=\mathrm{SN} \times 100 / \mathrm{TN}=$ ripening index $(\mathrm{RI})$.

${ }^{*} P<0.05$; *** $P<0.001$. 
peptides and, therefore, have a relevant impact on hard cheeses (Engels et al., 1997).

The RI (the percentage of SN to the $\mathrm{TN}$ at $\mathrm{pH} 4.6$ ) indicates the proportion of casein progressively digested by proteases and peptidases, and is one of the main indexes for cheese ripening (McSweeney, 2004). Casein breakdown during ripening leads to an increase in carboxylic acid and ammonia compounds that constitute the SN fraction. The RI mean value was significantly higher in cheeses from milk cooled at $12^{\circ} \mathrm{C}$ than in cheeses cooled at $18^{\circ} \mathrm{C}$. This may be due to plasmin release that increased during milk refrigeration. FajardoLira et al. (2000) found a decrease in plasminogen and an increase in plasmin activity during the storage of refrigerated milk. After the same ripening time, experimental Grana Trentino cheeses showed lower RI values than those usually observed in Parmigiano Reggiano and Grana Padano (Pecorari et al., 1997; Mucchetti and Neviani, 2006a), probably due to a slower ripening process in Grana Trentino.

\section{Free AA in Grana Trentino}

Glutamate was the most abundant AA in all cheeses, followed by leucine, lysine, valine, and serine (Table 3 ). These $5 \mathrm{AA}$ alone constituted more than $50 \%$ of the total FAA recovered from all of the cheeses. The FAA mean concentrations, with the exception of histidine, cytosine, and ornithine, were lower in cheeses produced with milk cooled at $18^{\circ} \mathrm{C}$ (Table 3 ), and probably dependent on the SN values, which were also significantly different (Table 2). No difference was found among milk treatments, for total and most of the single FAA, if the amount of each FAA was normalized to the SN value, with the exceptions of histidine, glycine, and lysine. Probably the milk temperature during storage before cheesemaking significantly affected the overall casein breakdown during cheese ripening but did not affect the proteolytic activities responsible for single FAA concentrations that are usually due to starter and nonstarter bacteria enzymatic activities on small peptides (Lemieux and Simard, 1992). The higher SN mean values, measured in cheeses produced with milk cooled at $12^{\circ} \mathrm{C}$, were probably due to increased plasmin activity. If the FAA amounts were normalized to $\mathrm{SN}$, differences among the cheeses were not significant, indicating that the storage conditions of the milk had no influence on the proteolytic activity of cheese microflora during ripening (McSweeney, 2004).

Specific FAA may be precursors of cheese flavor compounds upon enzymatic and chemical transformations; in general, the total FAA may contribute to the background cheese flavor (Christensen et al., 1999), but a specific link between typical cheese flavor and total FAA content has not always been reported (Engels et al., 1997).

\section{Analysis of VOC}

Many VOC have been identified in different cheese varieties (Curioni and Bosset, 2002). Under the analytical conditions adopted in the present work, 39 compounds were identified by GC-MS analysis of the volatile fraction of 18-mo ripened Grana Trentino cheeses: alcohols, aldehydes, ketones, ethyl esters, FA, and other compounds (Table 4). The cheeses were characterized by large amounts of FA and esters rather than alcohols, aldehydes, and ketones.

The ester concentrations were higher in the cheeses produced from milk treatment WTC than in cheeses cooled at $12^{\circ} \mathrm{C}$ (Table 4 ). The most abundant were ethyl isobutanoate and hexanoate esters, whose concentrations in cheeses from milk treatment WTC were above the odor threshold recorded by Curioni and Bosset (2002) and Dahl et al. (2000). Ethyl hexanoate ester plays an important role in the aroma profiles of aged Italian cheeses such as Grana Padano, Pecorino, and Ragusano (Curioni and Bosset, 2002). Arora et al. (1995) reported that ethanol is the most frequent alcohol found in cheese; this probably explains why all of the esters identified were ethyl derivatives. Therefore, ester production in the cheeses from milk treatment WTC may be due to the concomitant increase of the short- and medium-chain FA that results from the hydrolysis of triglycerides by lactobacilli (Dahl et al., 2000).

Free FA are important components among cheese VOC. Both butyric and hexanoic acids are generally the main VOC of Grana Padano (Curioni and Bosset, 2002). Qian and Reineccius (2002) affirmed that octanoic acid conferred strong sweaty, cheesy, lipolyzed notes, whereas heptanoic and nonanoic acids exhibited weak aromas in Parmigiano Reggiano cheese.

The pattern of VOC was qualitatively richer in the cheeses from milk treatment WTC (Table 4), which showed higher concentrations of total ethyl esters and FA than cheeses from milk cooled at 18 and $12^{\circ} \mathrm{C}$. No significant difference was found in the contents of acetic, propionic, and isovaleric acids. Butyric, hexanoic, and octanoic acids contents were always significantly higher in the cheeses from milk treatment WTC than from milk cooled at 18 and $12^{\circ} \mathrm{C}$. Cheeses from milk cooled at $12^{\circ} \mathrm{C}$ were supposed to be more subjected to higher FFA contents, due to putative lipolytic activities of psychrotrophic bacteria enzymes, but the observed amounts of FFA in cheeses from milk cooled at $12^{\circ} \mathrm{C}$ 
Table 3. Total amount of free AA (FAA, $\mathrm{mg} / \mathrm{kg}$ of cheese) and percent of FAA on soluble nitrogen (FAA/SN, $\mathrm{mg} / \mathrm{kg}$ of cheese) in 18-mo ripened Grana Trentino cheese (mean values $\pm \mathrm{SD}$ ) from different milk treatments: milk stored without temperature control and delivered by churns (WTC), milk stored at $18^{\circ} \mathrm{C}\left(18^{\circ} \mathrm{C}\right)$, and milk stored at $12^{\circ} \mathrm{C}\left(12^{\circ} \mathrm{C}\right)$ for $12 \mathrm{~h}$

\begin{tabular}{|c|c|c|c|c|}
\hline \multirow{2}{*}{$\begin{array}{l}\text { FAA and } \\
\text { FAA/SN }\end{array}$} & \multicolumn{3}{|c|}{ Treatment } & \multirow[b]{2}{*}{ Significance } \\
\hline & WTC & $18^{\circ} \mathrm{C}$ & $12^{\circ} \mathrm{C}$ & \\
\hline Asp & $192 \pm 16^{\mathrm{ab}}$ & $174 \pm 14^{\mathrm{a}}$ & $210 \pm 22^{\mathrm{b}}$ & $* * *$ \\
\hline $\mathrm{Asp} / \mathrm{SN}$ & $1.45 \pm 0.14$ & $1.39 \pm 0.15$ & $1.46 \pm 0.17$ & $\mathrm{NS}^{1}$ \\
\hline Glu & $999 \pm 97^{\mathrm{ab}}$ & $924 \pm 88^{\mathrm{a}}$ & $1,100 \pm 120^{\mathrm{b}}$ & $* *$ \\
\hline Glu/SN & $7.51 \pm 0.84$ & $7.4 \pm 1.2$ & $7.31 \pm 0.69$ & NS \\
\hline Asn & $259 \pm 49$ & $252 \pm 45$ & $288 \pm 42$ & NS \\
\hline Asn/SN & $1.95 \pm 0.37$ & $2.04 \pm 0.48$ & $2.00 \pm 0.28$ & NS \\
\hline Ser & $302 \pm 19^{\mathrm{ab}}$ & $280 \pm 30^{\mathrm{a}}$ & $310 \pm 30^{\mathrm{b}}$ & $*$ \\
\hline Ser/SN & $2.27 \pm 0.20$ & $2.24 \pm 0.27$ & $2.17 \pm 0.28$ & NS \\
\hline Gln & $27.9 \pm 8.8$ & $32 \pm 12$ & $32.0 \pm 5.7$ & NS \\
\hline Gln/SN & $0.21 \pm 0.06$ & $0.25 \pm 0.07$ & $0.21 \pm 0.03$ & NS \\
\hline His & $185 \pm 17$ & $180 \pm 31$ & $177 \pm 25$ & NS \\
\hline $\mathrm{His} / \mathrm{SN}$ & $1.39 \pm 0.10^{\mathrm{a}}$ & $1.44 \pm 0.22^{\mathrm{a}}$ & $1.23 \pm 0.14^{\mathrm{b}}$ & $* * *$ \\
\hline Gly & $113 \pm 16^{\mathrm{ab}}$ & $103 \pm 13^{\mathrm{a}}$ & $119 \pm 16^{\mathrm{b}}$ & $* *$ \\
\hline Gly/SN & $1.50 \pm 0.15^{\mathrm{ab}}$ & $1.30 \pm 0.23^{\mathrm{a}}$ & $1.73 \pm 0.33^{\mathrm{b}}$ & $* * *$ \\
\hline Thr & $212 \pm 14^{\mathrm{ab}}$ & $198 \pm 21^{\mathrm{a}}$ & $222 \pm 21^{\mathrm{b}}$ & $* *$ \\
\hline Thr/SN & $1.60 \pm 0.15$ & $1.59 \pm 0.22$ & $1.54 \pm 0.16$ & NS \\
\hline Cit & $50 \pm 53$ & $85 \pm 79$ & $64 \pm 71$ & NS \\
\hline $\mathrm{Cit} / \mathrm{SN}$ & $0.37 \pm 0.37$ & $0.69 \pm 0.63$ & $0.47 \pm 0.53$ & NS \\
\hline $\operatorname{Arg}$ & $244 \pm 58$ & $188 \pm 78$ & $221 \pm 94$ & NS \\
\hline $\mathrm{Arg} / \mathrm{SN}$ & $1.85 \pm 0.49$ & $1.49 \pm 0.64$ & $1.51 \pm 0.62$ & NS \\
\hline Ala & $158 \pm 16^{\mathrm{ab}}$ & $148 \pm 18^{\mathrm{a}}$ & $163 \pm 16^{\mathrm{b}}$ & $*$ \\
\hline $\mathrm{Ala} / \mathrm{SN}$ & $1.19 \pm 0.14$ & $1.18 \pm 0.20$ & $1.13 \pm 0.11$ & NS \\
\hline $\mathrm{GABA}^{2}$ & $16 \pm 15$ & $16 \pm 12$ & $24 \pm 21$ & NS \\
\hline GABA/SN & $0.12 \pm 0.12$ & $0.13 \pm 0.10$ & $0.16 \pm 0.13$ & NS \\
\hline Tyr & $125 \pm 21$ & $119 \pm 21$ & $137 \pm 22$ & NS \\
\hline Tyr/SN & $0.94 \pm 0.19$ & $0.97 \pm 0.24$ & $0.96 \pm 0.15$ & NS \\
\hline $\mathrm{NH}_{4}^{\prime}$ & $65 \pm 28$ & $68 \pm 49$ & $56 \pm 18$ & NS \\
\hline $\mathrm{NH}_{4} / \mathrm{SN}$ & $0.48 \pm 0.18$ & $0.53 \pm 0.33$ & $0.39 \pm 0.11$ & NS \\
\hline $\operatorname{Trp}+$ Met & $198 \pm 46$ & $190 \pm 33$ & $226 \pm 39$ & NS \\
\hline $\operatorname{Trp}+$ Met/SN & $1.50 \pm 0.39$ & $1.54 \pm 0.33$ & $1.57 \pm 0.27$ & NS \\
\hline Val & $388 \pm 30^{\mathrm{ab}}$ & $320 \pm 110^{\mathrm{a}}$ & $407 \pm 43^{\mathrm{b}}$ & $* *$ \\
\hline Val/SN & $2.91 \pm 0.31$ & $2.61 \pm 0.93$ & $2.83 \pm 0.24$ & NS \\
\hline Phe & $276 \pm 33^{\mathrm{ab}}$ & $239 \pm 79^{\mathrm{a}}$ & $299 \pm 37^{\mathrm{b}}$ & $* *$ \\
\hline Phe/SN & $2.08 \pm 0.33$ & $1.95 \pm 0.69$ & $2.08 \pm 0.25$ & NS \\
\hline Ile & $283 \pm 18^{\mathrm{ab}}$ & $264 \pm 25^{\mathrm{a}}$ & $293 \pm 27^{\mathrm{b}}$ & $* *$ \\
\hline Ile/SN & $2.13 \pm 0.21$ & $2.12 \pm 0.24$ & $2.04 \pm 0.21$ & NS \\
\hline Leu & $471 \pm 83$ & $449 \pm 70$ & $509 \pm 60$ & NS \\
\hline Leu/SN & $3.56 \pm 0.75$ & $3.64 \pm 0.81$ & $3.55 \pm 0.49$ & NS \\
\hline Orn & $9.0 \pm 4.7$ & $12.3 \pm 9.4$ & $10.0 \pm 8.7$ & NS \\
\hline Orn/SN & $0.07 \pm 0.03$ & $0.10 \pm 0.10$ & $0.07 \pm 0.07$ & NS \\
\hline Lys & $482 \pm 32$ & $437 \pm 43$ & $474 \pm 63$ & NS \\
\hline Lys/SN & $3.62 \pm 0.21^{\mathrm{a}}$ & $3.49 \pm 0.38^{\mathrm{ab}}$ & $3.28 \pm 0.27^{\mathrm{b}}$ & ** \\
\hline$\Sigma$ FAA & $4,910 \pm 490^{\mathrm{ab}}$ & $4,550 \pm 350^{\mathrm{a}}$ & $5,220 \pm 510^{\mathrm{b}}$ & $* *$ \\
\hline$\Sigma \mathrm{FAA} / \Sigma \mathrm{SN}$ & $36.9 \pm 40$ & $37.7 \pm 7.0$ & $36.3 \pm 3.4$ & NS \\
\hline
\end{tabular}

\footnotetext{
${ }^{\mathrm{a}, \mathrm{b}}$ Values within a row with different superscript letters are significantly different $(P<0.05)$. ${ }^{1} P>0.05$.

${ }^{2} \gamma$-Aminobutyric acid.

$* P<0.05 ; * * P<0.01 ;{ }^{* * *} P<0.001$.
}

did not confirm this. Probably, the short refrigeration (about $12 \mathrm{~h}$ ) was not sufficient to allow the growth and activity of spoilage microflora.

The higher FFA and ester contents observed in cheeses from milk treatment WTC could be the result of stronger lipolysis that occurred when milk was delivered in churns. In such a transport, the fat globule membrane of milk has more chance to break and to release the fat. Strong and quick lipolysis is observed if the fat globule membrane suffers mechanical damage, as happens with the agitation that occurs in churns (Collins et al., 2003) The presence of lipases, and the consequent lipolysis, causes a breakdown of fat globules in cream and an increase of FFA in milk (Chen et al., 2003).

Alcohol compounds were generally found in low concentrations in all samples (Table 4) and no significant difference was observed, whatever the milk treatment. 
Table 4. Esters, FFA, alcohols, ketones, aldehydes, and other compounds $(\mathrm{mg} / \mathrm{kg}$ ) in the volatile fraction of 18-mo ripened Grana Trentino cheese (mean values \pm SD) from different milk treatments: milk stored without temperature control and delivered by churns (WTC), milk stored at $18^{\circ} \mathrm{C}\left(18^{\circ} \mathrm{C}\right)$, and milk stored at $12^{\circ} \mathrm{C}$ $\left(12^{\circ} \mathrm{C}\right)$ for $12 \mathrm{~h}^{1}$

\begin{tabular}{|c|c|c|c|c|}
\hline \multirow[b]{2}{*}{ Item } & \multicolumn{3}{|c|}{ Treatment } & \multirow[b]{2}{*}{ Significance } \\
\hline & WTC & $18^{\circ} \mathrm{C}$ & $12^{\circ} \mathrm{C}$ & \\
\hline \multicolumn{5}{|l|}{ Ester } \\
\hline Acetate ethyl ester & $0.01 \pm 0.00$ & $0.02 \pm 0.01$ & $0.02 \pm 0.01$ & $\mathrm{NS}^{2}$ \\
\hline Isobutanoic acid ethyl ester & $0.09 \pm 0.06$ & $0.08 \pm 0.05$ & $0.05 \pm 0.03$ & NS \\
\hline Butanoic acid ethyl ester & $0.36 \pm 0.27^{\mathrm{a}}$ & $0.22 \pm 0.19^{\mathrm{ab}}$ & $0.17 \pm 0.08^{\mathrm{b}}$ & $* *$ \\
\hline Hexanoic acid ethyl ester & $0.27 \pm 0.15^{\mathrm{a}}$ & $0.16 \pm 0.09^{\mathrm{ab}}$ & $0.11 \pm 0.04^{\mathrm{b}}$ & $* * *$ \\
\hline Octanoic acid ethyl ester & $0.02 \pm 0.01$ & $0.01 \pm 0.01$ & $0.01 \pm 0.01$ & NS \\
\hline$\Sigma$ Esters & $0.75 \pm 0.46^{\mathrm{a}}$ & $0.49 \pm 0.33^{\mathrm{ab}}$ & $0.36 \pm 0.13^{\mathrm{b}}$ & $* *$ \\
\hline \multicolumn{5}{|l|}{ FFA } \\
\hline Acetic acid & $41 \pm 18$ & $35 \pm 16$ & $28.6 \pm 8.6$ & NS \\
\hline Propionic acid & $0.8 \pm 1.8$ & $0.14 \pm 0.20$ & $0.09 \pm 0.19$ & NS \\
\hline Butyric acid & $117 \pm 42^{\mathrm{a}}$ & $66 \pm 15^{\mathrm{b}}$ & $35 \pm 9.0^{\mathrm{c}}$ & $* * *$ \\
\hline Isovaleric acid & $0.57 \pm 0.39$ & $0.53 \pm 0.35$ & $0.36 \pm 0.22$ & NS \\
\hline Valeric acid & $0.50 \pm 0.20^{\mathrm{a}}$ & $0.25 \pm 0.08^{\mathrm{b}}$ & $0.13 \pm 0.05^{\mathrm{c}}$ & $* * *$ \\
\hline Hexanoic acid & $151 \pm 77^{\mathrm{a}}$ & $65 \pm 12^{\mathrm{b}}$ & $34 \pm 11^{\mathrm{c}}$ & $* * *$ \\
\hline Heptanoic acid & $0.87 \pm 0.26^{\mathrm{a}}$ & $0.33 \pm 0.07^{\mathrm{b}}$ & $0.18 \pm 0.09^{\mathrm{c}}$ & $* * *$ \\
\hline Octanoic acid & $34 \pm 21^{\mathrm{a}}$ & $13.4 \pm 3.4^{\mathrm{b}}$ & $7.3 \pm 3.6^{\mathrm{b}}$ & $* * *$ \\
\hline Nonanoic acid & $1.05 \pm 0.20^{\mathrm{a}}$ & $0.76 \pm 0.32^{\mathrm{ab}}$ & $0.59 \pm 0.55^{\mathrm{b}}$ & * \\
\hline Decanoic acid & $4.0 \pm 2.6^{\mathrm{a}}$ & $1.46 \pm 0.85^{\mathrm{b}}$ & $0.82 \pm 0.40^{\mathrm{b}}$ & $* * *$ \\
\hline$\Sigma \mathrm{FA}$ & $351 \pm 140^{\mathrm{a}}$ & $182 \pm 38^{\mathrm{b}}$ & $106 \pm 20^{\mathrm{c}}$ & $* * *$ \\
\hline \multicolumn{5}{|l|}{ Alcohol } \\
\hline 2-Heptanol & $0.02 \pm 0.01$ & $0.01 \pm 0.01$ & $0.02 \pm 0.02$ & NS \\
\hline$\Sigma$ Alcohols & $0.03 \pm 0.01$ & $0.02 \pm 0.01$ & $0.03 \pm 0.04$ & NS \\
\hline \multicolumn{5}{|l|}{ Ketones and aldehydes } \\
\hline 3-Methyl-butanal & $0.02 \pm 0.01$ & $0.02 \pm 0.01$ & $0.03 \pm 0.01$ & NS \\
\hline 2-Pentanone & $0.24 \pm 0.13$ & $0.16 \pm 0.05$ & $0.16 \pm 0.10$ & NS \\
\hline 2-Heptanone & $0.29 \pm 0.15$ & $0.23 \pm 0.08$ & $0.26 \pm 0.12$ & NS \\
\hline 2-Nonanone & $0.03 \pm 0.02$ & $0.03 \pm 0.01$ & $0.03 \pm 0.01$ & NS \\
\hline$\Sigma$ Ketones and aldehydes & $0.61 \pm 0.29$ & $0.46 \pm 0.09$ & $0.50 \pm 0.23$ & NS \\
\hline \multicolumn{5}{|l|}{ Other compound } \\
\hline$\Sigma$ Other compounds & $0.06 \pm 0.08$ & $0.03 \pm 0.03$ & $0.05 \pm 0.06$ & NS \\
\hline
\end{tabular}

${ }^{\mathrm{a}-\mathrm{c}}$ Values within a row with different superscript letters are significantly different $(P<0.05)$.

${ }^{1}$ Compounds with an amount $<0.01 \mathrm{mg} / \mathrm{kg}$ are not indicated.

${ }^{2} P>0.05$.

${ }^{*} P<0.05 ;{ }^{* *} P<0.01 ;{ }^{* * *} P<0.001$.

Aldehydes and ketones were found in small amounts (Table 4) and no differences were found in relation to the milk treatment before cheesemaking. Probably they did not accumulate in cheese because they were converted to the corresponding alcohols or acids (Lemieux and Simard, 1992). Aromatic and pyrazine compounds (other compounds in Table 4) were found always in small amounts, and no differences could be related to any milk treatment.

\section{Principal Component Analysis}

The variables that were significantly different between the 3 treatments after ANOVA were used to perform PC analysis, to explore their role in determining differences among the cheeses. The data matrix was made with 38 cheese samples and 25 input variables. Taking into account that input variables differed in magnitude, the correlation matrix was used. Three principal components accounted for $75 \%$ of the total variance. Figure 1 shows the cheese sample distribution in the 2-dimensional coordinate system defined by $\mathrm{PC} 1$ and $\mathrm{PC} 2$, accounting for 42 and $22 \%$ of total variance, respectively. High negative loadings with PC1 (|loading values $\mid \geq 0.60$ ) were found for most of the variables related to cheese proteolysis: all $\mathrm{AA}, \mathrm{SN}$, and RI. The variables having positive high loadings with PC1 (loading values $\geq 0.65$ ) were all FFA. The variables having high negative loadings with PC2 (|loading values $\mid \geq 0.60$ ) were all the esters and FFA. Total bacterial and mesophilic rod counts in cheese showed positive loadings with both $\mathrm{PC} 1$ and $\mathrm{PC} 2$. In relation to PC1 versus PC2 (Figure 1), the component PC1 distinguished the groups of cheese produced with milk cooled at $12^{\circ} \mathrm{C}$ from both WTC milk and $18^{\circ} \mathrm{C}$-cooled milk. In fact, the cheeses obtained from milk cooled at $12^{\circ} \mathrm{C}$ were characterized by higher levels of SN and AA. Principal component 2 described further differences 
between cheeses produced with milk treatment WTC and the other 2 milk treatments $\left(18\right.$ and $12^{\circ} \mathrm{C}$ cooled), probably due to the higher esters and FFA values in cheese from milk treatment WTC. Seven out of 10 of the cheeses produced with milk cooled at $18^{\circ} \mathrm{C}$ showed positive values both for $\mathrm{PC} 1$ and $\mathrm{PC} 2$, probably due to their higher microbial counts.

\section{CONCLUSIONS}

In this work, the relative impact of milk storage and delivery temperature on Grana Trentino cheese quality was determined. Milk refrigeration at $12^{\circ} \mathrm{C}$ on farm and the once-per-day delivery to the dairy factory is part of modernization and scale up of Grana Trentino production, and contrasts with traditional milk storage without refrigeration and delivery by churns. The influence of different milk storage temperatures and delivery systems on the microbiological and physicochemical characteristics of the cheeses was evaluated in factory-scale experimental cheesemaking trials. In a previous study (Endrizzi et al., 2012), we demonstrated that a panel of experts could not discern sensory differences among cheeses from WTC treatment or from milk cooled at 18 or $12^{\circ} \mathrm{C}$. However, chemical results from the actual study suggest that both the milk transport and storage temperature could affect the cheese ripening and its composition. The higher FFA and ester contents in experimental Grana Trentino cheeses produced in the traditional system (WTC milk treatment) showed that milk delivery by churns could enhance lipolysis activities, probably as consequence of mechanical breakdown of the fat globule membrane of milk. The larger amount of soluble nitrogen in Grana Trentino cheeses produced with milk stored at $12^{\circ} \mathrm{C}$ for $12 \mathrm{~h}$ before delivery showed that lower temperatures favored greater cheese proteolysis and faster ripening. The RI of Grana Trentino cheeses from milk cooled at $12^{\circ} \mathrm{C}$ were higher and closer to those of other hard Italian cheeses (Grana Padano and Parmigiano Reggiano). Consequently, milk storage at $12^{\circ} \mathrm{C}$ for $12 \mathrm{~h}$ and once-per-day delivery could be used in Grana Trentino production, because it does not affect microbial milk traits and has a positive effect on cheese in terms of time ripening.

\section{ACKNOWLEDGMENTS}

This study was financed by Provincia Autonoma di Trento. We acknowledge the Trentingrana Consortium staff for the help given us and the management. We

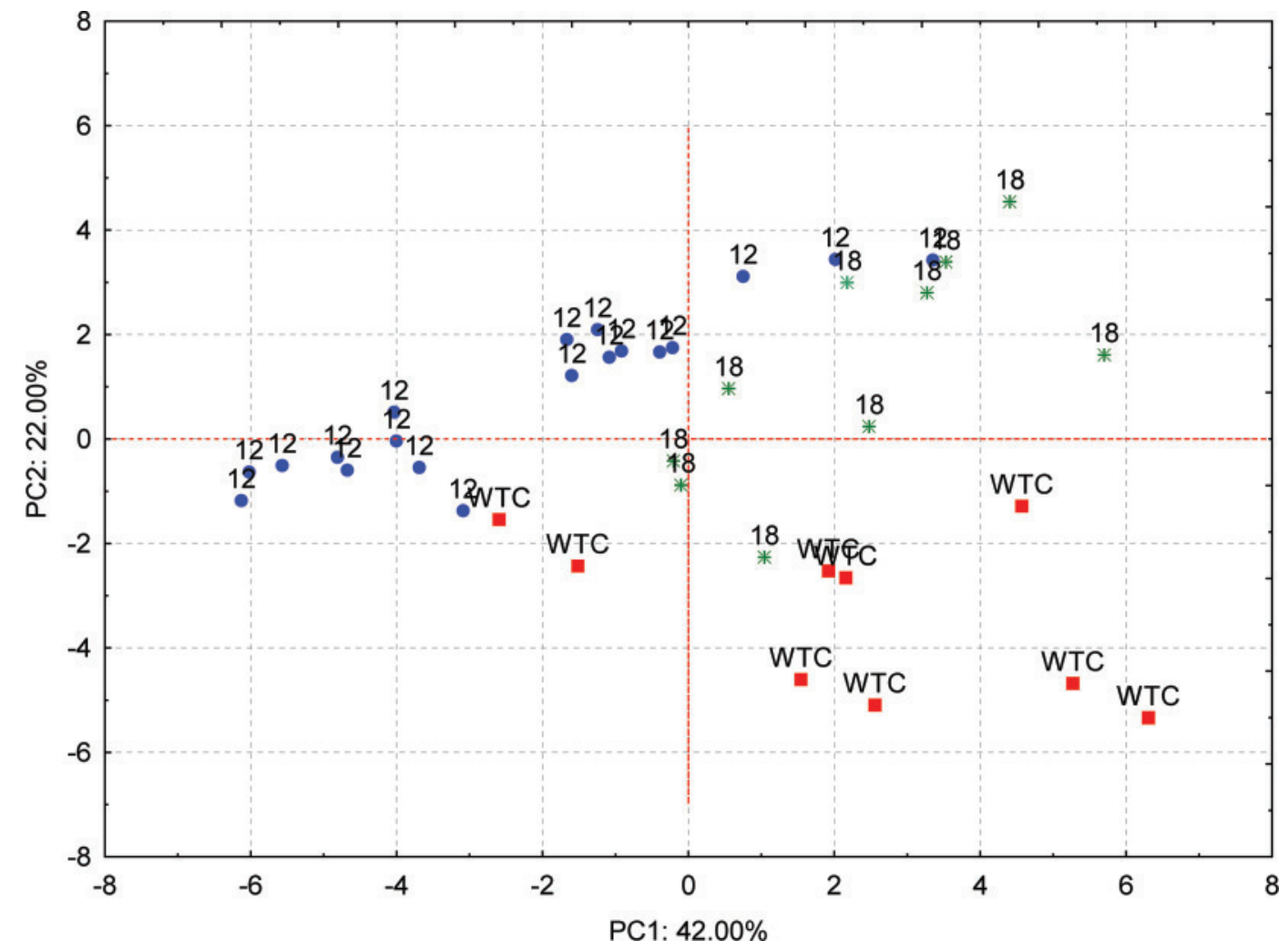

Figure 1. Score plot of the first and second principal component (PC) according to PC analysis of 38 Grana Trentino samples obtained from the 3 different milk treatments: milk stored without temperature control and delivered by churns (WTC; red squares), milk stored at $18^{\circ} \mathrm{C}$ (green stars), and milk stored at $12^{\circ} \mathrm{C}$ for $12 \mathrm{~h}$ (blue circles). Color version available in the online PDF. 
are grateful to Kieran Tuohy (Food Quality and Nutrition Area, IASMA Research and Innovation Centre, Fondazione Edmund Mach, Trentino, Italy) for critical reading of the article.

\section{REFERENCES}

Alais, C. 2000. Science du lait. Principes des techniques laitieres. Pages 89-157 (Ch. 6) in I protidi del latte - La caseina e il fenomeno della coagulazione. Tecniche Nuove, Milan, Italy.

Arora, G., F. Cormier, and B. Lee. 1995. Analysis of odor-active volatiles in Cheddar cheese headspace by multidimensional GC/MS/ sniffing. J. Agric. Food Chem. 43:748-752.

Biggs, D. A. 1978. Instrumental infrared estimation of fat, protein and lactose in milk: Collaborative study. J. Assoc. Off. Anal. Chem. 61:1015-1034.

Bütikofer, M., M. Rüegg, and Y. Ardö. 1993. Determination of nitrogen fractions in cheese: Evaluation of a collaborative study. Lebensm. Wiss. Technol. 26:271-275.

Carlin, S., and G. Versini. 2005. La caratterizzazione dei formaggi trentini attraverso la frazione volatile. Pages 231-239 in Caratterizzazione di formaggi tipici dell'arco alpino: Il contributo della ricerca. Istituto Agrario di San Michele all'Adige, Trento, Italy.

Chen, L., R. M. Daniel, and T. Coolbear. 2003. Detection and impact of protease and lipase activities in milk and milk powders. Int. Dairy J. 13:255-275.

Christensen, J. E., E. G. Dudley, J. A. Pederson, and J. L. Steele. 1999. Peptidases and amino acid catabolism in lactic acid bacteria. Antonie Van Leeuwenhoek 76:217-246.

Collins, Y. F., P. L. H. McSweeney, and M. G. Wilkinson. 2003. Lipolysis and free fatty acid catabolism in cheese: A review of current knowledge. Int. Dairy J. 13:841-866.

Coppola, R., M. Nanni, M. Iorizzo, A. Sorrentino, E. Sorrentino, C. Chiavari, and L. Grazia. 2000. Microbiological characteristics of Parmigiano Reggiano cheese during the cheesemaking and the first months of the ripening. Lait 80:479-490.

Coppola, R., M. Nanni, M. Iorizzo, A. Sorrentino, E. Sorrentino, and L. Grazia. 1997. Survey of lactic acid bacteria isolated during the advanced stages of the ripening of Parmigiano Reggiano cheese. J. Dairy Res. 64:305-310.

Cousin, M. A. 1982. Presence and activity of psychrotrophic microorganisms in milk and dairy products: A review. J. Food Prot. 45:172-207.

Curioni, P. M. G., and J. O. Bosset. 2002. Key odorants in various cheese types as determined by gas chromatography-olfactometry. Int. Dairy J. 12:959-984.

Dahl, S., F. K. Tavaria, and F. X. Malcata. 2000. Relationships between flavour and microbiological profiles in Serra da Estrela cheese throughout ripening. Int. Dairy J. 10:255-262.

De Marchi, M., G. Bittante, R. Dal Zotto, C. Dalvit, and M. Cassandro. 2008. Effect of Holstein Friesian and Brown Swiss breeds on quality of milk and cheese. J. Dairy Sci. 91:4092-4102.

Endrizzi, I., A. Fabris, F. Biasioli, E. Aprea, E. Franciosi, E. Poznanski, A. Cavazza, and F. Gasperi. 2012. The effect of milk collection and storage conditions on the final quality of Trentingrana cheese: Sensory and instrumental evaluation. Int. Dairy J. 23:105-114. http://dx.doi.org/10.1016/j.idairyj.2011.10.004.

Engels, W. J. M., R. Dekker, C. de Jong, R. Neeter, and S. A. Visser. 1997. A comparative study of volatile compounds in the watersoluble fraction of various types of ripened cheese. Int. Dairy J. $7: 255-263$.

Fajardo-Lira, C., M. Oria, K. D. Hayes, and S. S. Nielsen. 2000. Effect of psychrotrophic bacteria and of an isolated protease from Pseudomonas fluorescens M3/6 on the plasmin system of fresh milk. J. Dairy Sci. 83:2190-2199.
Franceschi, P., S. Sandri, M. Pecorari, P. Vecchia, F. Sinisi, and P. Mariani. 2008. Effects of milk storage temperature at the herd on cheesemaking losses in the manufacture of Parmigiano-Reggiano cheese. Vet. Res. Commun. 32(Suppl. 1):S339-S341.

Franciosi, E., L. Settanni, N. Cologna, A. Cavazza, and E. Poznanski. 2011. Microbial analysis of raw cows' milk used for cheese-making: Influence of storage treatments on microbial composition and other technological traits. World J. Microbiol. Biotechnol. 27:171-180.

Gatti, M., C. Lazzi, L. Rossetti, G. Mucchetti, and E. Neviani. 2003. Biodiversity in 236 Lactobacillus helveticus strains present in natural whey starter used for Parmigiano Reggiano 237 cheese. J. Appl. Microbiol. 95:463-470.

Gripon, J. C., M. J. Desmazeaud, D. Le Bars, and J. L. Bergere. 1975. Étude du rôle des micro-organismes et des enzymes au cours de la maturation des fromages. II. Influence de la présure commerciale. Lait 55:502-516.

IDF (International Dairy Federation). 1982. Cheese and processed cheese - Determination of total solids content (Reference method). FIL-IDF 4/A:1982. IDF, Brussels, Belgium.

IDF (International Dairy Federation). 1988. Cheese and processed cheese-Determination of chloride content (Potentiometric titration method). FIL-IDF 88/A:1988. IDF, Brussels, Belgium.

Larcher, R., G. Nicolini, D. Bertoldi, and L. Bontempo. 2004. Azotati a basso peso molecolare in formaggi trentini. Pages 131-142 in Quaderni dell'Istituto Agrario di S. Michele all'Adige, 1. Atti Convegno "Caratterizzazione di formaggi tipici trentini. Il contributo della ricerca scientifica". F. Gasperi and G. Versini, ed. Tipolitografia TEMI, Trento, Italy.

Lemieux, L., and R. E. Simard. 1992. Bitter flavour in dairy products. II. A review of bitter peptides from caseins: Their formation, isolation and identification, structure masking and inhibition. Lait $72: 335-382$

Malacarne, M., A. Summer, E. Fossa, P. Formaggioni, P. Franceschi, M. Pecorari, and P. Mariani. 2006. Composition, coagulation properties and Parmigiano-Reggiano cheese yield of Italian Brown and Italian Friesian herd milks. J. Dairy Res. 73:171-177.

McSweeney, P. L. H. 2004. Biochemistry of cheese ripening. Int. J. Dairy Technol. 57:127-144.

Mucchetti, G., and E. Neviani. 2006a. Microbiologia e tecnologia lattiero-casearia. Pages 489-582 (Ch. 6) in Schede tecniche di alcuni formaggi italiani. Tecniche Nuove, Milan, Italy.

Mucchetti, G., and E. Neviani. 2006b. Microbiologia e tecnologia lattiero-casearia. Pages 304-313 (Ch. 5) in Il Formaggio. Tecniche Nuove, Milan, Italy.

NIST/EPA/NIH (National Institute of Standards and Technology/ Environmental Protection Agency/ National Institutes of Health). 2005. NIST Mass Spectral Library. National Institute of Standards and Technology, US Secretary of Commerce, Washington, DC.

Pecorari, M., E. Fossa, S. Sandri, and I. Mariani. 1997. Andamento della proteolisi nel corso della maturazione del Parmigiano Reggiano. Sci. Tecn. Latt. Cas. 48:61-72.

Qian, M., and G. A. Reineccius. 2002. Identification of aroma compounds in Parmigiano-Reggiano cheese by gas chromatography/ olfactometry. J. Dairy Sci. 85:1362-1369.

Savini, E. 1946. Analisi del latte e dei latticini. Hoepli, Milan, Italy.

Snoeren, T. H. M., and J. A. M. van Riel. 1979. Milk proteinase, its isolation and action on $\alpha_{\mathrm{s} 2^{-}}$and $\beta$-casein. Milchwissenschaft 34:528-530.

Tavaria, F. K., P. J. M. Reis, and F. X. Malcata. 2006. Effect of dairy farm and milk refrigeration on microbiological and microstructural characteristics of matured Serra da Estrela cheese. Int. Dairy J. 16:895-902.

Wiedmann, M., D. Weilmeier, S. S. Dineen, R. Ralyea, and K. J. Boor. 2000. Molecular and phenotypic characterization of Pseudomonas spp. isolated from milk. Appl. Environ. Microbiol. 66:2085-2095. 